\title{
Sustaining the Supply of Ship Officers:Making a Case for Succession Planning in Seafarer Recruitment
}

\author{
Livingstone Caesar \\ Australian Maritime College, Locked Bag 1397, Launceston, 7250, Tasmania, Australia \\ *Corresponding Author: dlcaesar@amc.edu.au
}

Copyright (C) 2013 Horizon Research Publishing All rights reserved.

\begin{abstract}
The traditional cadet training system as discussed in the human resource literature on seafarers is epitomic of a succession planning system which primarily ensures that there is a reliable pool of talents from which shipping companies could pick future ship officers; but the vagaries of globalisation coupled with economic pressures is changing the complexion of cadet training for the shipping industry. As a result, what are currently left of cadet training are the relics of poor recruitment practices from shipping industry employers which is evidenced by high attrition rates among cadets. Ensuring a constant supply of cadets to fill the position of retiring and departing ship officers is a necessity; hence the need for a career and talent planning system - succession planning. This conceptual paper examines how succession planning for seafarers can be used as tool towards ensuring sustainability of ship officer supply for employers within the global shipping industry. In particular, the paper focuses on how certain peculiar aspects of the shipping industry; makes succession planning an imperative solution towards ensuring sustainability of skilled labour supply. The paper concludes with recommendations and directions for future research to draw greater attention to solutions for the greater officer shortage.
\end{abstract}

Keywords Seafarers, Shipping, Succession Planning, Recruitment, Training, Cadets, Attrition

\section{Introduction}

The global shipping industry is experiencing a shortage of ship officers; which is set to escalate in the future as the world economy moves out of recession [1-5]. Traditionally, ship officers are the end product of cadets who are made to undergo a combination of both classroom and shipboard training over an average period of 10 years $[5,6]$. Cadet training can therefore be regarded as a backbone of the system by which seafarers are groomed to become ship officers [5, 7-9]. This is a sort of talent supply chain which is currently under threat from a host of challenges due to the peculiar nature of the shipping industry. The key challenges necessitating a need for effective strategies towards the recruitment and training of cadets include: an increasingly ageing global ship officer profile [10], lack of interest in a seafaring career among the youth and high rates of attrition among cadets $[2,3,5,7,8]$. All these translate into a need for succession planning, to ensure an effective management of the career ambitions of cadet trainees in order to reduce wastage which has been identified in research as one of the major factors contributing to the shortage of ship officers [5, 11]. Hence, an effective succession planning for seafaring will mean that the attitude of shipping industry employers towards the sustainability of labour would not be reactive or demand driven but rather it is increasingly becoming necessary that strategies used to shore up labour requirements in the shipping industry assume a proactive approach [12].

The high rate of attrition among cadets is extensively discussed in the literature $[5,9,13,14]$. The most common reasons given for this phenomenon are: lack of genuine opportunities for career advancement $[10,12]$, long lead time involved in grooming cadets to become officers, inhuman treatment from mentors of cadets at sea [5, 7, 8, 13], long periods of waiting for training berths [9, 15], poor working conditions at sea and the lack of commitment from shipping industry employers towards the training of seafarers [16].

Due to the aforementioned list of growing challenges confronting an effective training and grooming of cadets into ship officers, this paper therefore advocates a need for human resource managers within the shipping industry to employ succession planning tools at the organisational level to stabilise the flow of seafarers from the lower ranks to the higher echelons of a ship's crew complement.

\section{Talent Management and Succession Planning}

Talent management has become one of the most important components of human resource management in many organisations within the $21^{\text {st }}$ century. Sourcing for skilled talents to meet the corporate objectives of an 
organisation is now a daunting task for employers. Many researchers advocate succession planning as an effective strategic human resource tool which could be harnessed to ensure the recruitment and sustenance of appropriate talents channels in an era that have seen keen competition for skilled talents among organisations [17]. Succession planning is a proactive process that is used for the development of development of organisational talent in order to build sufficient bench strength and preserve specialised knowledge $[18,19]$. Hence succession planning transcends beyond the ordinary realm of staff replacement as it should be construed as an all-inclusive talent management activity involving not only the sourcing of talent but its grooming as well [20]. In the same vein, Rothwell [19] outlines the features of an effective succession planning strategy as addressing the need for critical backups and cutting across the entire organisation; designed to cater for all job levels - not limited to only top management.

Apart from the need to ensure a constant pool of talent from which an organisation could tap in the future to fill sensitive positions, there are other reasons that lend support to the need for succession planning in organisations. Table 1 provides a glimpse into the other reasons why succession planning is very important in the management of modern day organisations. Contemporary researchers on talent management and succession planning dating from beginning of the century (the year 2000) have focused on its strategic role within the entire organisation setup $[18,19,21]$. Taylor and McGraw [22] concluded that succession management is becoming a strategic and critical factor for organisational success. As a result, many organisations are beginning to acknowledge the relevance of having an effective succession planning system in place to deliver reliable solutions for their human resource challenges.

\subsection{Best Practice Succession Planning}

One important issue that has emerged essential is the criteria that can be employed in rating a succession planning strategy as best practice. Based on the perused literature, Table 2 provides an overview of what can be deemed as a best practice in succession plan. Due to the common link shared by succession plans and the respective career plans of employees [22], it is imperative that any succession planning system designed by an organization takes into consideration career goals of their employees at all levels [19]. Hence, the core of any best practice succession plan is the ability to effectively monitor, mentor and nurture organizational talents to take up leadership positions in the future when the need arises. Anything short of such an objective defeats the primary reason for which succession plans are designed and implemented in organisations.

\section{Seafaring and Succession Planning}

The shipping industry is faced with a shortage of skilled talents, specifically ship officers $[23,24]$. There is a general consensus in the literature that this shortage is more likely to escalate and may give rise to a more volatile global seafarer labour market [4, 5]. The need for shipping industry employers to employ succession planning as a strategic human resource tool to deal with the existing shortage of ship officers is principally based on a number of factors.

In the first place, there is a high rate of attrition reported [see for example, 5, 13] among seafarers which needs to be managed strategically. This wastage of skilled is common among cadets and officers and is primarily a major contributor to the prevailing labour crisis in the shipping industry [25]. Naturally, the cadet system is a lynchpin of the process through which ship officers are supplied to meet future demands for skilled labour onboard oceangoing ships. Future supply is however under serious threat from the high wastage rates among cadets in maritime training institutions as well as those onboard ships $[5,15]$. Increasing wastage among cadets is principally attributed to unpleasant experiences at sea and lack of proper mentorship from superiors which culminate in a breaking of the psychological contract $[5,12,26]$. To address the root causes of attrition among cadets, succession planning could prove useful in ascertaining the differences in expectations as people go to sea and have them managed accordingly [12]. Wastage is not only prevalent among cadets but is equally a challenge with regards to the retention of ship officers. There is a very high rate of mobility among ship officers [26]. Recent findings [4, 27] suggest that most seafarers may not stay at sea beyond ten years. This is a disturbing trend when one considers the importance of retaining trained officers to meet future offshore labour demands. Unfortunately, a lot of these officers are moving from the ships to pursue landside maritime careers or have mining organisations as their destination. The lack of genuine opportunity for career progression to the level of ship master is one of the major reasons for the high mobility among ship officers. Succession planning offers a realistic chance for shipping industry employers to ensure that the diverse career expectations of their employees are catered for in order to reduce the high rate of mobility.

The shipping industry is highly globalised with a diverse workforce [28]. As a result, managing seafarers with varied cultural backgrounds is a major challenge [29]. In fact, many organisations are struggling to manage the emerging diversity within their workforce [30]. Rothwell [19] found that succession planning is effective in the management and advancement of staff in diverse workforce environments. This can be equally effective in the case of the seafaring labour market which shares most of the attributes of a diverse workforce due to its globalised nature. 
Table 1. Reasons for the need of succession planning in organisations

\begin{tabular}{|c|c|}
\hline AUTHOR(S) & REASONS FOR SUCESSION PLANNING \\
\hline Kowalewski, Moretti [31] & $\begin{array}{l}\text { - Prepare companies for future critical vacancies of middle and } \\
\text { senior management positions }\end{array}$ \\
\hline Rothwell [18], [19] & $\begin{array}{ll}\text { - } & \text { Contributes to strategic business plan of the organisation } \\
\text { - } & \text { Increases opportunities for high potential workers } \\
\text { - } & \text { Taps the potential for intellectual capital in an organisation } \\
\text { - } & \text { Helps individuals realise their career plan in an organisation } \\
\text { - } & \text { Encourages the advancement of diverse groups } \\
\text { - } & \text { Improves employee morale } \\
\text { - } & \text { Cope with effect of downsizing } \\
\text { - } & \text { Improves employee ability to respond to changing demands in the } \\
\text { - } & \text { Decision environment } \\
\text { the organisation }\end{array}$ \\
\hline Barnett and Davis [32] & Improves the bottom line (financial performance) of organisations \\
\hline Crumpacker and Crumpacker [33] & $\begin{array}{ll}\text { - } & \text { Ensures continuity of leadership in organisations } \\
\text { - } & \text { Retains knowledge within an organisation } \\
\text { - } & \text { Aids in the sharing and transfer of knowledge in an organisation }\end{array}$ \\
\hline Cannon and McGee [21] & $\begin{array}{l}\text { - Develops a strategy to determine current and future human } \\
\text { resource needs of an organisation }\end{array}$ \\
\hline Atwood [34] & $\begin{array}{l}\text { - Ensures that hiring decisions align with strategic plans and goals } \\
\text { of the organisation } \\
\text { - Aids the sourcing of best candidates for positions due to its } \\
\text { flexibility } \\
\text { - Ensure long term commitment to development of organisational } \\
\text { talent } \\
\text { - Develops talent pools at various levels of the organisation }\end{array}$ \\
\hline
\end{tabular}

Table 2. Criterion of a best practice succession plan

\begin{tabular}{|c|c|}
\hline $\begin{array}{l}\text { RESEARCHER (S) AND } \\
\text { TITLES } \\
\end{array}$ & BEST PRACTICE SUCESSION PLANNING \\
\hline $\begin{array}{l}\text { Holland [35] } \\
\text { The art of business planning: Who } \\
\text { will fill your shoes }\end{array}$ & 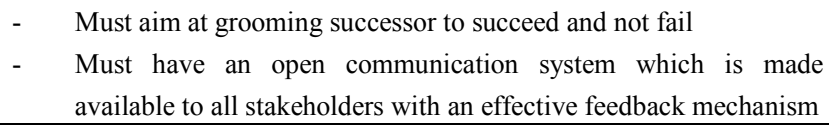 \\
\hline $\begin{array}{c}\text { Friedman [36] } \\
\text { Leadership succession }\end{array}$ & $\begin{array}{l}\text { - } \quad \text { Highly organised } \\
\text { - } \quad \text { Has a system of checks and balances } \\
\text { - } \quad \text { Has sufficient resources allocated for its implementation } \\
\text { - } \quad \text { Has extensive and comprehensive information on people and } \\
\text { positions } \\
\text { - Uses criteria for selection decisions based on technical competence } \\
\text { and not political ties } \\
\text { - Has staff who are credible but who do not "own" the system }\end{array}$ \\
\hline $\begin{array}{l}\text { Rothwell [19] } \\
\text { Effective succession planning: } \\
\text { Ensuring leadership continuity and } \\
\text { building talent from within }\end{array}$ & $\begin{array}{l}\text { - It must be guided by a "big picture roadmap or model" } \\
\text { - Hands-on involvement of the organisation's CEO and other senior } \\
\text { leaders } \\
\text { - Use competency models to clarify what type of talent the } \\
\text { organisation's leaders want to nurture } \\
\text { - Development and implementation of an effective performance } \\
\text { management system } \\
\text { - Clarify future organisational competency needs for the } \\
\text { achievement of strategic objectives } \\
\text { - Employ individual development plans to narrow developmental }\end{array}$ \\
\hline
\end{tabular}




\begin{tabular}{|c|c|}
\hline & $\begin{array}{l}\text { gaps } \\
\text { - Develop descriptions of the values and ethical standards required } \\
\text { and assess people relative to those as well as competencies } \\
\text { - } \quad \begin{array}{l}\text { Build a viewpoint that high-potential talent is a shared resource } \\
\text { rather than owned by specific managers }\end{array} \\
\text { - Use leadership development efforts to build shared competencies } \\
\text { needed for the future }\end{array}$ \\
\hline $\begin{array}{l}\text { Hills [37] } \\
\text { Succession planning - or smart } \\
\text { talent management? }\end{array}$ & $\begin{array}{l}\text { - Involve the talents (beneficiaries) in the process } \\
\text { Employ a hybrid of experience, coaching and training for } \\
\text { development of talents } \\
\text { - Assess leadership potential of staff using the 3Cs (Collaboration, } \\
\text { Co-ordination and Communication) }\end{array}$ \\
\hline $\begin{array}{c}\text { Atwood [34] } \\
\text { Succession planning basics }\end{array}$ & $\begin{array}{l}\text { - Must be supported by top management and be communicated } \\
\text { frequently to staff. This will aid employee build-in. } \\
\text { Co-ordinated with organisation's strategic plan and tailored to } \\
\text { address changes in strategic policy direction } \\
\text { - Developed by a team of representatives from different levels of the } \\
\text { organisation to ensure broader understanding and meeting of true } \\
\text { company needs not perceived needs } \\
\text { Uses systematic methods in identification of future leaders of the } \\
\text { organisation and grooming them to assume leadership roles. } \\
\text { Effective communication to inform employees of skills needed to } \\
\text { qualify as leaders in the organisation. } \\
\text { Simplicity of plan is a necessity to ensure easy implementation as } \\
\text { well as avoid perpetuation of "firefighting" syndromes and } \\
\text { replacement hiring. } \\
\text { Incorporate open communication methods which aim to achieve } \\
\text { employee input. This will help the planning team to know the } \\
\text { concerns, opinions and ideas of employees which can be useful } \\
\text { Elements of accountability, evaluation and follow-up must be } \\
\text { integrated into the system to aid monitoring }\end{array}$ \\
\hline $\begin{array}{l}\text { Taylor and McGraw [22] } \\
\text { Succession management practices } \\
\text { in Australian organisations }\end{array}$ & $\begin{array}{l}\text { - Requires substantial on-going organisational commitment across } \\
\text { all levels } \\
\text { - } \quad \text { Support from senior management for the development of staff } \\
\text { identified as high potentials }\end{array}$ \\
\hline
\end{tabular}

There is need for succession planning in seafaring due to the industry's peculiar nature, which is mainly driven by inherent diversity and global forces [13]. To start with, the time span involved in training people to become full-fledged ship officers is averagely ten years $[1,6]$ and this means long lead time between the period people enter into the industry till they become officers [38]. The long period is due to the combination of both classroom and shipboard training schemes during which several negative happenings lead to loss of labour to the shipping industry. There is an urgent need for succession plan in shipping organisations to effectively manage the challenges that endanger the sustainability of future supply of ship officers during the long training period.

Age has already emerged as an issue among seafarers; with studies [see for example, 39, 40] confirming that the age of ship officers from traditional crew supply nations is quite advanced. An ageing workforce for shipping and the apparent lack of interest among the younger generation for a career at sea is deepening the current labour crisis bedevilling the industry. A better interpretation of the high age profile of officers from traditional maritime nations is that a large number of them will go on retirement at a particular period and commensurate replacement becomes an obvious necessity. All these translate into a need for succession planning, to ensure an effective management of the career ambitions of cadet trainees in order to reduce wastage which has been identified in research as one of the major factors contributing to the shortage of ship officers.

\section{Conclusion}

This paper has outlined the keys issues discussed in the general literature on succession planning with a particular focus on what should be construed as best practice. Ensuring a constant supply of cadets to fill the position of retiring and departing ship masters is a necessity [7]; hence the need for a career and talent planning system for shipping industry employers. This is because, lack of employment prospects which creates career uncertainty, emerged as the 
root cause of cadet attrition; and this can effectively be addressed at the organization level by way of a succession planning strategy. The reasons for succession planning as given in Table 1 coupled with the criterion of best practice succession planning in Table 2 shows that there are many labour-related challenges in the shipping industry which can be addressed through an organisational succession plan. For instance, Hills [37] explains that a succession plan can help to identify talent needs within organisations and develop people to meet such needs even before they arrive.

During the process of nurturing trainee cadets to become ship officers, the many problems that arise can be addressed through a succession plan. For example, the glass ceiling syndrome which present practical obstacles to the career progression of cadets [see for example, 41] who desire to become ship masters (especially organisational culture which may not favour the promotion of seafarers from certain regions to the position of ship officers) can be addressed through a succession plan which will ensure that that cadets are selected to become officers based on the criteria of competence rather than political or cultural affiliation.

An example can also be cited of retrenchment of seafarers which occurs during economic downturns [3] as shipowners are compelled to tinker with crewing costs to stay competitive over the period. All these things contribute to increasing wastage among cadets [see for example, 5] and other category of seafarers as the need to sustain employee morale and loyalty becomes greater. Considering that the availability of opportunities for career progression is a major reason for people staying at sea [42], any sense of job insecurity which is influenced by poor organisational practices such as retrenchment and labour inequity can trigger the movement of cadets to land-side sectors of the industry or even join other industries as they become anxious over the certainty of their future career prospects [7]. The work of Asyali, Zorba [43] explains that the solution to high wastage among seafarers, especially during periods of economic downturns is for shipping industry employers to approach challenges common with the recruitment, training and retention of seafarers using strategic human resource policies. Succession planning is an effective strategic management tool with which shipping companies can stabilise their pool of labour regardless of the prevailing economic climate.

A model succession planning for cadets should be effectively communicated to them at the inception of their career and must take into consideration age, gender and ethnicity so that it can be rid of bias in any form. With this, realistic career expectations of cadets can be ascertained during the recruitment phase and addressed accordingly to improve their retention as well since the career expectations of seafarers differ [12, p.4].This is necessary to avoid trivial tensions related to diversity (gender, ethnicity and age) which develop onboard ships and have the potential of endangering operational safety as well as jeopardize crew retention programmes. In a study that sought to examine seafarer cadet training in the United Kingdom, Gould [9] found an association between cadets whose expectations were met and long-term commitment at sea (more than 5 years). In that study, those who felt their expectations were not met eventually resigned. This brings to light the need for effective planning and management of expectations for cadets who may be regarded as talents needed for future staff replenishment.

Succession planning can be construed as a long term approach to talent development which when adopted in the maritime industry can help alleviate the shortage of ship officers. Donner [44] however explained that even though the shortage of ship officers has been around for a very long time, industry employers tend to rely on stop-gap measures which are rather not capable of providing any lasting solution to the problem but only temporary relief. The short-term measures commonly used by shipping companies and ship management outfits to address the shortage of ship officer include: using the services of crewing agencies in emerging breeding grounds [45], re-employment of retired officers [44], poaching of officers [46], quick elevation of newly qualified officers to the rank of masters, lengthening of duty tours of officers and reducing manning scales [47]. Apart from the fact that these temporary measures do not present a realistic opportunity to secure a reliable supply chain for the future supply of ship officers, Donner [44] examined that most of them have negative ramifications for maritime safety. Turker and $\operatorname{Er}$ [48] found that apart from shortage of talent, the quick promotion of senior officers to the rank of masters may be done to induce organisational commitment among them as they feel indebted to the employer as a result. Even though the motive may be good, the practice in itself is not worthy of emulation as the repercussions for industry far outweighs the singular gains to be made by the employer.

From the perspective of acquiring and retaining skilled labour, a question needs to be asked of how shipping industry employers can become sustainable organisations for the future? This is because the current practices used by shipping companies and other seafarer-employing outfits to employ seamen need refocusing. As a matter of fact, the recruitment and employment of seafarers needs to take a long-term approach in order to ensure sustainability of supply regardless of the prevailing economic climate. Any programme outlined to achieve sustainability of supply must have a career development programme for new entrants and existing employees as its foundation [46]. Hence, an effective succession planning for seafaring will mean that the attitude of shipping industry employers towards the sustainability of labour should not be reactive or demand driven but rather it is increasingly becoming necessary that strategies used to shore up labour requirements assume a proactive approach.

\section{REFERENCES}


[1] BIMCO/ISF, BIMCO/ISF Manpower Update: The worldwide demand for and supply of seafarers, Dalian Maritime University and Institute for Employment Research, University of Warwick. 2010.

[2] Cahoon, S. and H. Haugstetter. Shipping, shortages and generation $\mathrm{Y}$. in 8th International Conference on Maritime Training, Communication and Technology (MARTECH). Singapore, 2008

[3] Cahoon, S., H. Haugstetter, and P. Bhaskar. Overcoming seafarer shortages: Human resource management and marketing strategies for a sustainable future. in International Association of Maritime Economists Conference. Lisbon, Portugal, 2010

[4] Deloitte. Challenge to the industry - Securing skilled crews in today's marketplace. Research on Shipping and Ports 2011 30th May, 2012]; Available from: www.deloitte.com/view/en_GX/global/industries/energy-res ources/shipping/.

[5] Gekara, V.O., Understanding attrition in UK maritime education and training. Globalisation, Societies and Education, Vol.7 No.2, 217-232, 2009.

[6] Dyer-Smith, M., Shipboard organization-the choices for international shipping. Journal of Navigation, Vol.45 No.3, 414-424, 1992.

[7] Gekara, V.O., The stamp of neoliberalism on the UK tonnage tax and the implications for British seafaring. Marine Policy, Vol.34 No.3, 487-494, 2010.

[8] Gekara, V.O. What about skills? A discussion of the role of skills in the strategic positioning of ports as essential catalysts of trade and economic growth. in Australasian Transport Research Forum Canberra, Australia: PATREC, 2012

[9] Gould, E.A., Towards a total occupation: A study of UK merchant navy officer cadetship, in Cardiff School of Social Sciences, 2010, Cardiff University: Cardiff.

[10] McLaughlin, H.L., Seafarers and seafaring, in The Blackwell Companion to Maritime Economics, W.K. Talley, Editor, Wiley-Blackwell: Oxford, UK. 321-332, 2012

[11] Magramo, M. and L. Gellada, A noble profession called seafaring: The making of an officer. International Journal on Marine Navigation and Safety of Sea Transportation, Vol.3 No.4, 475-480, 2009.

[12] Caesar, L., S. Cahoon, and J. Fei. Breaking the psychological contract and managing expectations: Developing solutions for the shortage of ship officers. in International Association of Maritime Economists Conference. Marseille, 2013

[13] Gekara, V.O., Globalisation, state strategies and the shipping labour market: The UK's response to declining seafaring skills, in Seaman International Research Centre2008, Cardiff University: Cardiff.

[14] Pekcan, C., M. Barnett, and D. Gatfield, A national survey of cadets, Warsash Maritime Centre: Warsash. 2003.

[15] Zhao and M.S.V. Amante, Chinese and Filipino seafarers: a race to the top or the bottom? Modern Asian Studies, Vol.39 No.3, 535-557, 2005.
[16] Wild, A., Securing the future of Australian shipping through officer education and training, in Maritime Logistics and Management2012, University of Tasmania: Launceston.

[17] Garman, A.N. and J. Glawe, Succession Planning. Consulting Psychology Journal: Practice and Research, Vol.56 No.2, 119-128, 2004.

[18] Rothwell, W.J., Career planning and succession management: developing your organization's talent--for today and tomorrow, Greenwood Publishing Group. 2005.

[19] Rothwell, W.J., Effective succession planning: Ensuring leadership continuity and building talent from within. 4th ed, Amacom Books: New York. 2010.

[20] Poduch, S. and W. Rothwell, Introducing technical (not managerial) succession planning. Public Personnel Management, Vol.33 No.4, 405-19, 2004.

[21] Cannon, J. and R. McGee, Talent management and succession planning. 2nd ed, Chartered Institute of Personnel and Development: London. 2007.

[22] Taylor, T. and P. McGraw, Succession management practices in Australian organizations. International Journal of Manpower, Vol.25 No.8, 741-758, 2004.

[23] Fei, J., An empirical study of the role of information technology in effective knowledge transfer in the shipping industry. Maritime Policy \& Management, Vol.38 No.4, 347-367, 2011.

[24] Leggate, H., The future shortage of seafarers: will it become a reality? Maritime Policy \& Management, Vol.31 No.1, 3-13, 2004.

[25] Couper, A., Perceptions and attitudes of seafarers towards maritime regulations: An historical perspective, in The regulation of international shipping: international and comparative perspectives: Essays in honour of Edgar Gold, A. Chircop, et al., Editors, Martinus Nijhoff Publishers: Leiden, Netherlands. 429-442, 2012

[26] Fei, J., Knowledge management in the shipping industry: the effects of human mobility on the organisational knowledge base and effective knowledge transfer practices : a perspective from China, in Department of Maritime and Logistics Management, 2009, University of Tasmania: Tasmania.

[27] Ljung, M., Function based manning and aspects of flexibility. WMU Journal of Maritime Affairs, Vol.9 No.1, 121-133, 2010 .

[28] Bloor, M. and H. Sampson, Regulatory enforcement of labour standards in an outsourcing globalized industry: the case of the shipping industry. Work, Employment \& Society, Vol.23 No.4, 711-726, 2009.

[29] Bocanete, P. and C. Nister. Challenges and cultural identity issues of maritime human resources in the globalized world. in 5th International Vilnius Conference. Vilnius, Lithuania, 2009

[30] Stevens, F.G., V.C. Plaut, and J. Sanchez-Burks, Unlocking the benefits of diversity: All-inclusive multiculturalism and positive organisational change. The Journal of Applied Behavioral Science, Vol.44 No.1, 116-133, 2008.

[31] Kowalewski, S.J., L. Moretti, and D. McGee, Succession 
planning: Evidence from'best companies in New York'. International Journal of Management and Marketing Research, Vol.4 No.2, 99-108, 2012.

[32] Barnett, R. and S. Davis, Creating greater success in succession planning. Advances in Developing Human Resources, Vol.10 No.5, 721-739., 2008.

[33] Crumpacker, M. and J.M. Crumpacker, Succession planning and generational stereotypes: Should HR consider age-based values and attitudes a relevant factor or a passing fad? Public Personnel Management, Vol.36 No.4, 349-369, 2007.

[34] Atwood, C.G., Succession planning basics, American Society for Training and Development: United States of America. 2007.

[35] Holland, C., The art of business succession planning: Who will fill your shoes, Wiley: Melbourne. 2012

[36] Friedman, S.D., Leadership Succession, Transaction Publishers: New Jersey. 2011.

[37] Hills, A., Succession planning-or smart talent management? Industrial and Commercial Training, Vol.41 No.1, 3-8, 2009.

[38] Obando-Rojas, B., B.M. Gardner, and M. Naim, A system dynamic analysis of officer manpower in the merchant marine. Maritime Policy \& Management, Vol.26 No.1, 39-60, 1999.

[39] Mitroussi, K., Employment of seafarers in the EU context: Challenges and opportunities. Marine Policy, Vol.32 No.6, 1043-1049, 2008.

[40] Silos, J., et al., Trends in the global market for crews: A case study. Marine Policy, Vol.36 No.4, 845-858, 2012.

[41] Eler, G., et al., Officers' shortage: Viewpoints from stakeholders. International Journal on Marine Navigation and Safety of Sea Transportation, Vol.3 No.4, 471-474, 2009.

[42] Barnett, M., et al., Barriers to progress or windows of opportunity? A study in career path mapping in the maritime industries. WMU Journal of Maritime Affairs, Vol.5 No.2, $127-142,2006$

[43] Asyali, E., et al. Global economic crisis and the impact on human resources strategies for seafarers. 2010 3rd November, 2012]; Available from: http://193.243.196.149/wp-content/uploads/showcontent000 7.pdf.

[44] Donner, P. Reasons for and insurance implications of the manning crisis. in 2nd International Scientific Maritime Conference on Human Resources in the Shipping Industry: New Trends and Challenges in the 21st Century. Limassol, Cyprus., 2008

[45] Amante, M.S.V. Industrial democracy in the rough seas: The case of Philippine seafarers. in 56th annual meeting of Industrial Relations Research Association San Diego: Industrial Relations Research Association, 2004

[46] Magramo, M., et al., Officers as prostitutes: Myth or reality? (A study on poaching of officers in the Philippines). International Journal on Marine Navigation and Safety of Sea Transportation, Vol.4 No.3, 333-335, 2010.

[47] Hetherington, C., R. Flin, and K. Mearns, Safety in shipping: The human element. Journal of Safety Research, Vol.37 No.4, 401-411, 2006.

[48] Turker, F. and I.D. Er, Investigation of the root causes of seafarers' turnover and its impact on the safe speration of the ship. International Journal on Marine Navigation and Safety of Sea Transportation, Vol.1 No.4, 435-440, 2007. 